\title{
Correction to: Status of racial disparities between black and white women undergoing assisted reproductive technology in the US
}

David B. Seifer ${ }^{1}$, Burcin Simsek ${ }^{2}$, Ethan Wantman ${ }^{3}$ and Alexander M. Kotlyar ${ }^{1 *}$

Correction to: Reprod Biol Endocrinol 18, 113 (2020) https://doi.org/10.1186/s12958-020-00662-4

Following publication of the original article [1], the keywords term "racial disparities ART, racial disparities IVF, IVF racial disparities, and ART racial disparities" were not included. The keywords have been added.

The original article [1] has been updated.

\section{Author details}

'Department of Obstetrics, Gynecology and Reproductive Sciences, Yale School of Medicine, 330 Cedar St, New Haven, CT 06510, USA. ${ }^{2}$ Department of Statistics, University of Pittsburgh, Pittsburgh, PA 15260, USA. ${ }^{3}$ Redshift Technologies, New York, NY 10016, USA.

Published online: 30 July 2021

\section{Reference}

1. Seifer DB, Simsek B, Wantman E, et al. Status of racial disparities between black and white women undergoing assisted reproductive technology in the US. Reprod Biol Endocrinol. 2020;18:113. https://doi.org/10.1186/ s12958-020-00662-4.

\section{Publisher's Note}

Springer Nature remains neutral with regard to jurisdictional claims in published maps and institutional affiliations. original author(s) and the source, provide a link to the Creative Commons licence, and indicate if changes were made. The images or other third party material in this article are included in the article's Creative Commons licence, unless indicated otherwise in a credit line to the material. If material is not included in the article's Creative Commons licence and your intended use is not permitted by statutory regulation or exceeds the permitted use, you will need to obtain permission directly from the copyright holder. To view a copy of this licence, visit http://creativecommons.org/licenses/by/4.0/. The Creative Commons Public Domain Dedication waiver (http://creativeco mmons.org/publicdomain/zero/1.0/) applies to the data made available in this article, unless otherwise stated in a credit line to the data. 